\title{
Political communication in and about crises - Introduction to the Thematic Section
}

\author{
Julia Metag*, University of Münster, Department of Communication \\ Caroline Dalmus, University of Applied Sciences of the Grisons, SII Swiss Institute for \\ Information Science \\ *Corresponding author: julia.metag@uni-muenster.de
}

The financial crisis in Europe and the United States, the war in Syria, the refugee crisis, and terrorist attacks - crises seem to permeate everyday life and make headlines. Crisis as a central, persistent element of modern life has been the subject of scholarly discussions in various disciplines. Political communication research approaches crisis from two different angles. First, political crisis communication research deals with communication about political crises, such as political upheavals, protests, and subversions of governments and presidents. One of the most recent examples of a political crisis comes from Venezuela, where political changes and problems, such as corruption and undemocratic governance, have brought about economic problems (hyperinflation), a rising crime rate, hunger, and disease. Second, many other types of crises involve political communication because they also lead to policy reactions or at least discussion on their political aspects. For example, natural disasters typically provoke public discussion on the roles of political organizations and actors before, during, and after these disasters and the consequences for policy.

In communication science, organizational communication has so far most intensively dealt with crises as communicative events. Indeed, "currently, crisis communication is more of a subdiscipline in public relations and corporate communication" (Coombs \& Holladay, 2010, p. xxvi). However, recognition that every crisis has a political dimension makes exploring political communication perspectives on crises all the more relevant. The concept of crisis lies at the core of political crisis communication research. What is a crisis, and what constitutes it?

Common criteria emerge from definitions of crisis, most rooted in organizational communication research. A crisis usually is a specific event "that is unexpected, negative, and overwhelming" (Barton, 2001, p. 2) or a "turning point for better or worse" (Fink, 1986, p. 15). Thus, a crisis is commonly perceived as an event that has a clear beginning and end; that is, it is temporally limited. A crisis is also unexpected and unpredictable and interrupts routine, everyday practices (Coombs, 2010a). Moreover, crises are social constructs; events are not inherently crises but are crises because they are perceived and treated by people as such (Coombs, 2010b). The same event can be constructed as a crisis at one moment in time but not be perceived as such in other circumstances.

Crises can threaten the reputations of organizations, so crisis communication is aimed at preventing negative reputational effects. Crisis communication is quite simply defined as "the collection, processing, and dissemination of information required to address a crisis situation" (Coombs, 2010a, p. 20). Building on these characteristics, crisis communication research has identified four distinct phases at the core of the crisis management process: (1) prevention; (2) preparation; (3) response; and (4) learning (Coombs, 2005; Schwarz \& Löffelholz, 2014). In the prevention phase, the organization collects information about potential crises or factors that could precipitate crises in order to prevent them. In the preparation phase, the organization develops a plan establishing behavior and responsibilities 
during crises. The response phase is the most crucial phase of crisis management and encompasses the organization's reactions to the crisis, which can range from denying it and making excuses to dealing with it. In the final phase, the organization gathers information about the crisis it has endured to learn from it and be better prepared for future crises.

Within this context, several challenges to political communication research on crises can be identified. As mentioned, the concept of crisis so far has been primarily addressed by organizational communication research and has not yet been at the core of political communication research. As Udris argues in his commentary in this thematic section, political communication research has not developed crisis into a meaningful concept. The first challenge then is to provide such a concept and to construct a theoretical framework describing crisis from a political communication research perspective. The challenge can be seen by considering the characteristics of crisis mentioned. Not all events and phenomena called crises in political communication research have these characteristics. For example, many phenomena named crises do not have a clear beginning or end. Take, for example, the notion of the crisis of democracy. Neither are all crises completely unexpected. For instance, the refugee crisis from the war in Syria could have been expected. Moreover, long, ongoing crises are not necessarily exceptional anymore and, to a certain extent, have become routine. Consequently, political communication researchers sometimes seem to have difficulty differentiating between crisis and non-crisis situations.

Second, crisis communication research has been criticized for lacking theory, and only a very few theories (e.g., image repair theory and situational crisis communication theory) dominate the field (Diers-Lawson, 2017). This situation poses another challenge for political crisis communication research. These dominant theories have rarely been used in political communication research, and whether they are suitable for the field needs to be discussed. The challenge thus is to build a theoretical framework to analyze political crises, perhaps integrating theories from crisis communication into political communication or developing distinct theoretical approaches for political crises. The usefulness of political communication theories for crisis communication research should be examined.

Third, an unexpected crisis leads to reactive research (see Udris' commentary) because political communication scholars can only study crises that are underway or over. Thus, conducting proactive political crisis communication research presents another challenge. Fourth, defining crisis and conducting proactive research pose methodological challenges. Which methods are useful for analyzing the specific character of political communication during and about crises? Consider, for example, the role of social media in crisis communication research. Despite a large body of work on the uses of social media in crisis communication (e.g., Choi, 2012; Schultz \& Utz, 2013), deep investigations of proactive uses of digital methods are scarce in political crisis communication research. Newer methods are able to address the dynamic processes of unfolding crises (e.g., social network analysis), but they need to be implemented more when researching political crises. Fifth, as reviews of the existing literature have shown, crisis communication research generally is Western centric (Diers-Lawson, 2017). However, many forms of political crises also occur in Global South countries with less stable political systems. A stronger focus on these regions would benefit political crisis communication research.

Although unable to tackle all these challenges, the papers in this thematic section deal with political crisis communication in various ways and focus on different actors in the process of crisis communication, including political actors, the media, and the public. Political actors can be defined as those held responsible for or in charge of handling crises, whereas the media has the role of making crises visible, guiding the societal discourse, and offering information and perspectives to the public affected by crises. Wirz, Wettstein, Schulz, 
Ernst, Schemer, and Wirth focus on populist actors' use of crises to achieve political goals and the effectiveness of such behavior. They offer a relevant perspective on the topic because they do not focus on how actors try to handle crises but, rather, on how actors may strategically use crises to their own advantage. Especially for populist actors, crises pose opportunities because they facilitate selling politics. Through the use of specific styles such as dramatization and emotionalization, populists may even intensify the feeling of a crisis while acting as competent problem-solvers. Using content analysis and survey data, the authors show that such populist crisis rhetoric in the media does, in fact, affect citizens' attitudes. Regarding the issue of immigration, Wirz et al. demonstrate that in Switzerland, populist right-wing communication tends to mobilize those who feel attached to populist ideology.

Nitsch and Lichtenstein focus more heavily on media reporting on crises. Instead of analyzing everyday news coverage, they investigate a rarely researched genre in crisis communication: political satire. After discussing the shortcomings of regular news coverage on crises, the authors analyze to what extent German satire shows may compensate for such deficits. Their study covers the Ukraine crisis, Greek debt crisis, and migration crisis. While political satire does not add much new information to discussions - most likely because those shows use news media as their main sources of information - it enriches debates by offering counter-narratives and critical orientation. By commenting and criticizing, political satire can make debates originating from crises more multifaceted.

Finally, the general public is the primary subject of the paper by Kösters, Obert, Begenat, and Jandura. Focusing on the refugee crisis as a shared public issue in Germany, the authors investigate whether such a shared issue facilitates integration. They show that issue interpretations differ depending on the specific population group. Living environments shape perceptions of shared issues, resulting in varying evaluations of the crisis and thus different opportunities for successful immigration. In milieus characterized by extreme positions, the refugee crisis leads to polarization rather than integration, whereas milieus with political heterogeneity and diverse perspectives have potential for integration.

These three papers offer diverse perspectives on political crisis communication and illustrate the range of the issue. However, there remain many important, unanswered questions about political actors' decision making and responsibility, media crisis coverage, public perceptions of crisis, and their effects on the public. In the commentary concluding this thematic section, Udris highlights the strong fragmentation of the research field - despite growing interest in the topic in political communication research - and the need for a clear concept to enable researchers to identify crises, their causes, and their dynamics. Future researchers, therefore, can ask: In what circumstances can certain parties profit from crises, and when do crises endanger their reputations? To what extent does issue ownership give an advantage to political actors during crises? How do different media outlets deal with the dynamic development of crises in new information environments, and how does this affect the general public? Regarding the crisis communication process, from prevention to learning, more research is needed on how political actors and the media prepare for crises and what they learn from these situations for future crises. The papers in this thematic section present a starting point to answer such questions and offer promising outlooks for future research.

\section{References}

Barton, L. (2001). Crisis in organizations II. Cincinnati, OH: South-Western College Pub.

Choi, J. (2012). Crisis communication through Twitter. In S. Duhé (Ed.), New media and public relations ( $2^{\text {nd }}$ edition, pp. 311-319). New York: Peter Lang. 
Coombs, W. T. (2005). Crisis communication. In R. L. Heath (Ed.), Encyclopedia of public relations (pp. 222-225). Thousand Oaks, CA: Sage.

Coombs, W. T. (2010a). Parameters for crisis communication. In W. T. Coombs and S. J. Holladay (Eds.), The handbook of crisis communication (pp. 17-53). Oxford, UK: Wiley Blackwell.

Coombs, W. T. (2010b). Conceptualizing crisis communication. In R. L. Heath \& H. D. O'Hair (Eds.), Handbook of risk and crisis communication (pp. 99-118). New York: Routledge.

Coombs, W. T., \& Holladay, S. J. (2010). Preface. In W. T. Coombs \& S. J. Holladay (Eds.), Handbook of crisis communication (pp. xxvi-xxvii), Malden, MA: Wiley-Blackwell.

Diers-Lawson, A. (2017). A state of emergency in crisis communication: an intercultural crisis communication research agenda. Journal of Intercultural Communication Research, 46(1), 1-54. doi:10.1080/17475759.2016.1262891
Fink, W. (1986). Crisis management: Planning for the inevitable. New York: American Management Association.

Schultz, F., \& Utz, S. (2013). Krisenkommunikation und Soziale Medien in der vernetzten Gesellschaft - theoretische Perspektive und empirische Befunde [Crisis communication and social media in the network society - theoretical perspectives and empirical results]. In A. Thießen (Ed.), Handbuch Krisenmanagement [Handbook crisis management] (pp. 331-342). Wiesbaden, GE: Springer.

Schwarz, A., \& Löffelholz, M. (2014). Krisenkommunikation: Vorbereitung, Umsetzung, Erfolgsfaktoren [Crisis communication. Preparation, Implementation, Factors for Success.]. In: A. Zerfaß \& M. Piwinger (Eds.), Handbuch Unternehmenskommunikation [Handbook Corporate Communication] (pp. 1303-1319). Wiesbaden, GE: Springer. 